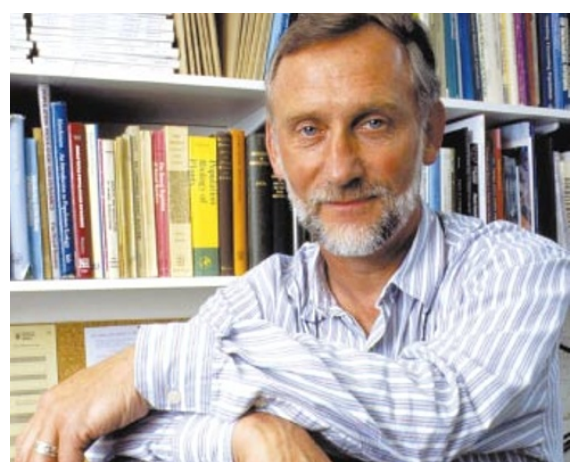

Lawton: 'no conspiracy against marine science.'

\section{Lawton named head of UK environment research agency}

[LONDON] John Lawton, director of the Centre for Population Biology at Imperial College, London, has been appointed to head the Natural Environment Research Council (NERC), Britain's main government funding agency for environmental research.

Lawton, who is already a member of NERC's governing council, will take up his post, initially for three years, in October. $\mathrm{He}$ replaces Sir John Krebs, who has been NERC's chief executive for the past five years.

The appointment has in general been widely welcomed. Lawton commands considerable respect, both as an ecologist — he has had 17 papers published in Nature and four in Science - and for his role as founding director of the Centre for Population Biology, which was set up 11 years ago.

But some members of the marine-science community say they are disappointed that a marine scientist was not appointed to head the research council. Lawton will be the second consecutive chief executive to have a background in zoology. Marine scientists feel that someone sharing their background would have been better motivated to lobby the government to raise funds for marine research, which has not fared as well as other environmental disciplines in recent years.

Lawton says he is aware of these concerns but, while declining to comment on them directly, he strongly denies any charges of a conspiracy against marine sciences in NERC.

He also says he is not planning any drastic changes to NERC's published three-year research agenda. But he adds that he is looking forward to developing interdisciplinary ideas within some of the agreed priority areas. These include exploring links between the environment and health, and between ecology and economics.

Lawton has a completely different personality to his predecessor. Krebs is noted for his diplomatic skills, whereas Lawton is usually unafraid to voice strong opinions, and has been described by one of his peers as "very persistent".

EhsanMasood

\title{
French research boosted by grants run by ministries
}

[PARIS] France last week awarded life sciences, information technology and social sciences the lion's share of a recently created FF1.2 billion (US $\$ 188$ million) special annual fund for research. The fund is administered directly by government ministries, not by the research agencies that usually distribute grants.

The money comes from a new fund for basic science, the National Science Fund, and the existing Fund for Technology Research, which had fallen into neglect before being refloated by the current government. Grants will be distributed through calls for proposals, reviewed by ministerial committees.

Six priorities were earmarked for extra support at a meeting of the interministerial committee for scientific and technological research, chaired by prime minister Lionel Jospin, and attended by 12 ministers whose responsibilities include aspects of research.

Life sciences won FF395 million, with FF80 million going to the National Genotyping Centre at Evry near Paris and FF60 million to the new national plant biotechnology programme, Génoplante. Information technology will receive FF175 million, and FF55 million will go to nanotechnology. Human and social sciences received an injection of FF85 million, urban studies FF75 million,
Earth and environmental sciences FF45 million, and energy research FF20 million.

A further FF100 million was earmarked for a competition to fund promising ideas for the creation of high-technology companies. And FF40 million will create a fund for young researchers, with the money distributed through a call for proposals for original ideas irrespective of discipline.

The increased prominence of central funding has come under fire from trade unions representing scientists, who are suspicious of grants being administered directly by government in a country where research has long been under the jurisdiction of independent research agencies.

But Claudine Laurent, an adviser to science minister Claude Allègre, says the science ministry has a duty to stimulate and coordinate "the priorities of the government", arguing that the research agencies still have considerable freedom, and that the government funding supports fundamental research.

Olivier Kahn, a chemist at the University of Bordeaux, welcomes what he says is a clear hierarchy of national research priorities, and an effort to redress well-known weaknesses of the French research system, such as insufficient attention to the needs of young scientists.

Eric Glover

\section{Funds promised for South African telescope}

[CAPE TOWN] Construction of the Southern African Large Telescope (SALT), which is planned to become the largest single telescope in the Southern Hemisphere, has moved closer with commitments to joint funding from overseas partners in Poland, the United States and Germany.

The South African government announced its commitment to provide half the funding for the telescope a year ago (see Nature 393,$403 ; 1998)$. With 84 per cent of the expected cost of $\$ 16.4$ million (without instrumentation) now committed, construction of the telescope will commence later this year. The telescope is expected to take five years to complete.

The largest overseas contributor so far is the Polish Ministry of Science, which has said it will provide $\$ 2.5$ million for the construction, with an extra $\$ 0.5$ million from a consortium of Polish universities and research institutions. A further \$1.2 million for construction costs and \$1 million for running costs over the first ten years has been promised by Rutgers University in the United States.

The third overseas partner is the
University of Göttingen in Germany, which has committed $\$ 1.3$ million towards the telescope's construction. Prospective partners that have not yet committed funds include Carnegie Mellon University, Iowa State University and the University of Wisconsin in the United States, and the astronomical community in New Zealand.

SALT will be have an effective diameter of 9.2 metres. Like its twin in the Northern Hemisphere, the Hobby-Eberly Telescope, recently built in Texas, SALT will be able to collect and analyse the light from many celestial objects at a time over a field of view of approximately 5 arcminutes.

Conventional telescopes need to move to track objects in the sky as the Earth rotates, but SALT will remain stationary, with a 5.5tonne 'tracker assembly' at the top of the telescope moving instead. This design limits observations to the time it takes a celestial object to move through 12 degrees, which translates to between 50 minutes and 2.5 hours, depending on how close to the Equator the telescope is located, but it seldom takes more than an hour to make a particular observation.
Michael Cherry 